\title{
Hoitotyöntekijöiden osaamisen kehittämistarpeet lähijohtajien ja hoitohenkilökunnan arvioimana
}

\author{
Sari Himanen ja Riitta Nikkola
}

\section{Johdanto}

Suomessa hoitajien koulutustaso vanhustyössä on muihin Pohjoismaihin verrattuna hyvä: kolmella neljäsosalla on vähintään kahden vuoden hoitotyön koulutus (Kröger ym. 2018). Vanhuspalvelujen hoitohenkilökunnasta suurin osa työskentelee lähihoitajana, joka on nimikesuojattu ammattinimike. Tosin nimikesuojattujen ammattihenkilöiden ammatissa voivat toimia muutkin henkilöt, joilla on riittävä koulutus, kokemus ja ammattitaito. (Laki terveydenhuollon ammattihenkilöistä, 559/94.) Työelämässä toimivien ammattilaisten osaaminen, sen arviointi ja vahvistaminen ovat nousseet aikaisempaa tärkeämpään asemaan, kun opiskelijoiden oppiminen on siirtynyt entistä enemmän työpaikoille ammatillisen koulutuksen reformin myötä (Laki ammatillisesta koulutuksesta 531/2017).

Hyvästä koulutustasosta huolimatta vain 37 prosenttia suomalaisista vanhustyöntekijöistä luotti Krögerin ja kumppaneiden (2018) tutkimustulosten mukaan siihen, että työtoverit ovat päteviä. Omaa osaamista lienee helpompi arvioida riittäväksi tai hyväksi, kuten noin kaksi kolmasosaa vanhusten parissa työskentelevistä hoitajista arvioi Kiljusen (2019) tutkimuksessa. Samoin kotihoidon henkilöstö on arvioinut hallitsevansa vanhustyön perustiedot ja taidot ja selviävänsä itsenäisesti asiakkaan kotona tehtävästä työstä siten, että kykenee vastaamaan asiakkaiden tarpeisiin (Tiikkainen \& Juntunen 2018).

Työntekijöiden osaamisella on vanhustyössä suuri vaikutus palvelun laatuun ja vaikuttavuuteen, samoin asiakkaiden kokemaan elämänlaatuun (Voutilainen ym. 2009; Räsänen 2017). Myös työntekijöiden työasenne vaikuttaa suuresti asiakaslähtöisyyden toteutumiseen ja uusien toimintatapojen käyttöönottoon (Saarela ym. 2019), joihin vanhusten hoidossa on todettu tarvetta havaittujen vakavien ja pitkäaikaisten laatuongelmien vuoksi.

Vanhusten perustarpeisiin vastaamisessa on todettu puutteita ja kohtelussa epäasiallisuutta. Hoitoa on kuvattu rutiininomaiseksi ja organisaatiolähtöiseksi, jolloin vanhusten yksilöllisyys ja vaikutusmahdollisuudet omaa elämää koskevaan päätöksentekoon on sivuutettu. (Voutilainen \& Löppönen 2016; Aejmelaeus \& Hetemäki 2019.) Henkilökunnalla on tunnistettu osaamisvajetta muun muassa kokonaisvaltaisen hyvinvoinnin tukemisessa, ohjauksessa ja aktiviteettien organisoinnissa (Arolaakso \& Tervaskanto-Mäentausta 2017; Kiljunen 2019), lääkehoidossa, pitkäaikaissairauksien ja geriatristen oireyhtymien hoidossa, vaativan hoitotyön ja hoitotoimenpiteiden hallinnassa (Bing-Jonsson ym. 2016; Tiikkanen \& Juntunen 2018) sekä dokumentoinnissa (Bing-Jonsson ym. 2016). Lisäkoulutustarvetta koettiin olevan 
eniten mielenterveys- ja päihdehoidon osaamisessa sekä koti- että ympärivuorokautisen hoidon yksiköissä. Lisäksi koulutustarpeita tunnistettiin teknologian hyödyntämisen alueella, saattohoidossa ja toimintakyvyn moniulotteisessa arvioinnissa. (Alastalo ym. 2018.)

\section{Tapaustutkimuksen tavoite ja toteutus}

Osana DIKI-hanketta (Digitaalinen itseopiskelu keinona hoivatyössä voimaantumiseen ja asiakastyytyväisyyden lisäämiseen, ESR 2017-2019) halusimme selvittää, miten palvelutalojen henkilöstön osaamista tulisi vahvistaa. Kartoitimme asiaa haastattelemalla lähijohtajia ja toteuttamalla henkilöstölle kyselyn. Tutkimustulosten perusteella on tarkoitus kehittää palvelutalojen henkilöstölle täydennyskoulutusta.

Tutkimuksen kohderyhmänä oli viiden hankkeeseen osallistuvan tamperelaisen palvelutalon henkilökunta. Aineiston keruut toteutettiin keväällä 2017. Kyseessä oli tapaustutkimus, jonka avulla pyrittiin ymmärtämään tutkittavaa ilmiötä kokonaisuutena, yhteiskunnallinen konteksti huomioon ottaen (Häikiö \& Niemenmaa, 2007, 42).

\section{Lähijohtajille toteutettu haastattelu}

Haastatteluteemoja oli kaksi: lähijohtajien näkemykset palvelutalon hoitohenkilöstöltä edellytettävän osaamisen painopisteistä ja lähijohtajien näkemykset oman organisaationsa henkilöstön osaamisen keskeisimmistä kehittämiskohteista. Haastattelu toteutettiin ryhmähaastatteluna, joka nauhoitettiin ja litteroitiin. Aineisto analysoitiin kahden haastatteluteeman ohjaamana; relevantit ilmaisut värikoodattiin, pelkistettiin ja järjestettiin teemoittain. Tulokset kuvataan tiivistettynä aineistoa edustavana kertomuksena. (Lodigo ym. 2006.)

Ryhmähaastatteluun osallistui kolmesta eri palvelutalosta yhteensä neljä lähijohtajaa,jotka olivat tehtävänimikkeiltään henkilöstöjohtaja, yksikön johtaja tai hoitotyön esimies. Heillä oli johdettavanaan 15-50 henkilöä.

\section{Henkilöstölle toteutettu kysely}

Palvelutalojen hoitohenkilöstön osaamista ja koulutustarpeita kartoitettiin strukturoidulla e-lomakekyselyllä. Mittari luotiin kirjallisuuden pohjalta, ja se sisälsi seitsemän kysymystä taustatiedoista, 38 Likert-asteikollista väittämää, joilla vastaaja arvioi samanmielisyyttään osaamista tai työskentelytapaa kuvaavien väittämien kanssa asteikolla 1-5 (1 = täysin eri mieltä, 5 = täysin samaa mieltä), ja 15 kysymystä koulutustarpeista, joihin vastattiin asteikolla 1-5 (1 = ei lainkaan koulutustarvetta, 5 = paljon koulutustarvetta).

Linkki kyselyyn lähetettiin sähköpostitse viiden palvelutalon kaikille hoitohenkilöstöön kuuluville $(\mathrm{N}=180)$. Vastauksia tuli 47 työntekijältä eli vastausprosentti oli 26. Aineisto analysoitiin Excel-ohjelmalla ja tulokset kuvataan suorina prosenttijakaumina. Henkilöstön osaamista ja koulutustarpeita kuvaavat tulokset esitetään lähijohtajien haastatteluaineiston analysoinnin tuloksena muodostuneiden teemojen mukaisesti.

Kyselyn vastaajista $(n=47)$ enemmistö $(77 \%)$ työskenteli lähihoitajana $(n=36)$. Sairaanhoitajia oli vastaajista seitsemän ja hoivaavustajia tai muita neljä. Vastaajista seitsemän oli enintään 25-vuotiaita ja kuusi yli 56-vuotiaita. Ikäluokkaan 26-35 vuotta sijoittui 19 vastaajaa ja 36-55-vuotiaisiin 18 vastaajaa. Vastaajista puolella oli työkokemusta korkeintaan 10 vuotta ja yhdeksällä henkilöllä yli 20 vuotta.

\section{Vanhustyössä tarvittava osaaminen}

Haastateltujen lähijohtajien näkemysten mukaan palvelutaloissa työskentelevällä hoitohenkilöstöllä tulisi olla laaja-alaista hoitotyön osaamista, koska ikäihmiset ovat terveydentilan ja toimintakyvyn suhteen heterogeeninen asiakasryhmä. Työ perustuu perushoitotyön 
hyvään hallintaan, mihin sisältyy hygienian ja ravitsemuksen turvaaminen, haavanhoito ja kuntoutus. Kliinisen hoitotyön osaamisessa edellytetään laaja-alaista perussairauksien ja sisätautien tuntemusta, niiden lääkehoidon ja muun hoidon osaamista, terveydentilan, voinnin ja toimintakyvyn havainnointia ja niihin liittyvien muutosten arviointia, lääkehoidon toteuttamisen osaamista, muistisairaan kohtaamista ja ensiaputaitoja sekä hyvää kirjaamisen ja raportoinnin taitoa.

Lähijohtajat näkivät keskeisenä osaamisena asiakaslähtöisen työotteen, johon kuuluu asiakkaan itsemääräämisoikeuden kunnioittaminen ja kyky luoda kodinomainen hoitoympäristö. Lisäksi vastaajat korostivat osaamisen painopisteissä vuorovaikutustaitoja, tiimityöskentelytaitoja, kykyä tukea yhteisöllisyyttä ja ergonomian osaamista.

\section{Vanhustyössä toteutuva osaaminen}

Henkilökunnasta lähes kaikki vastaajat arvioivat kykenevänsä huolehtimaan asukkaiden hygieniasta, ymmärtävänsä ravitsemuksen ja painehaavojen ehkäisyn merkityksen sekä osaavansa toteuttaa kuntouttavaa työotetta. Näillä perushoitotyön osa-alueilla korkeintaan 6 prosenttia vastaajista epäröi omaa osaamistaan tai toimintavalmiuttaan. Viidesosa vastaajista ei ollut varma, kykeneekö toteuttamaan laadukasta perushoitotyötä, ja neljäsosalla oli epävarmuutta jalkaterveyden edistämisen osaamisessa.

Kliinisen hoitotyön aihealueilla kaikki vastaajat, myös hoiva-avustajat, arvioivat osaavansa toteuttaa turvallista lääkehoitoa. Yli 90 prosenttia arvioi osaavansa arvioida asukkaan diabeteksen tasapainotilaa ja sydän- ja verisuonisairauksien yhteyttä henkilön olotilaan, huomioida eri sairaudet ja muistisairaan erityistarpeet hoitotyössään, toteuttaa asukaslähtöistä kirjaamista sekä hoitaa saattohoidossa olevaa asukasta. Mielenterveyden häiriöiden tunnistaminen oli ainoa teema, jossa kolmannes (34\%) vastaajista tunnisti osaamisessaan epävarmuutta.
Puolet vastaajista koki, että ei pysty vaikuttamaan työtehtäviinsä, 37 prosenttia arvioi, että ei pysty suoriutumaan työtehtävistä niin hyvin kuin haluaisi, ja 57 prosenttia ei kokenut työpaikan ilmapiiriä myönteiseksi.

\section{Osaamisen kehittämistarpeet lähijohtajien näkökulmasta}

Haastatellut lähijohtajat tunnistivat useita osaamisen kehittämistarpeita palvelutalojensa hoitohenkilöstöllä. Kommenteissaan he arvioivat lähinnä lähihoitajien osaamista, koska heitä on henkilöstössä eniten. Johtajien näkemyksen mukaan lähihoitajan koulutus ei anna työhön riittävää osaamista. He näkivät työkokemuksella ja asenteella olevan suuri merkitys osaamisen kehittymisessä.

Lähijohtajat arvioivat, että perushoitotyö ja asiakkaiden hygieniasta huolehtiminen toteutuu melko hyvin; tosin haastateltavat kertoivat, että toisinaan tapahtuu lapsuksia sekä hygienian hoidossa että aseptiikassa. Hoitotyön arjessa ilmenee oikomista, minkä lähijohtajat näkevät osaamisen puutteena, sillä hoitajan ammattitaitoon kuuluu tarkkuus hoitotyössä.

Kliinisessä hoitotyössä lääkehoidon osaaminen nousi keskeiseksi kehittämistarpeeksi. Lähijohtajat arvioivat, että lähihoitajat ovat kiinnostuneita lääkehoidon toteuttamisesta mutta heillä on puutteellinen osaaminen lääkeryhmien ja lääkkeiden rinnakkaisvalmisteiden tunnistamisessa sekä annosteltavien lääkkeiden antamisessa tarvittaessa ilman sairaanhoitajan ohjausta. Asukkaiden voinnin ja oireiden sekä lääkkeiden vaikutusten arviointiosaaminen, erityisesti lääkemuutosten yhteydessä, vaatii vahvistamista, samoin tieto siitä, milloin pitää konsultoida lääkäriä tai sairaanhoitajaa.

Kirjaamisen, raportoinnin ja dokumentoidun tiedon hyödyntämisen osaamista tulisi lähijohtajien mielestä vahvistaa, samoin RAIja Vivago-tulosten hyödyntämisen osaamista. Hoito- ja palvelusuunnitelmat laaditaan lähijohtajien näkemysten mukaan pääsääntöisesti 
hyvin, mutta parannettavaa on muutosten kirjaamisessa ja siinä, miten hoito- ja palvelusuunnitelmat viedään käytännön tasolle ohjaamaan suunnitelmallista hoitotyötä.

Haastattelun aikana toistui usein lähijohtajien näkemys, että asiakaslähtöisyys on tärkein osaamisen kehittämiskohde. Siinä on jo tapahtunut parannusta verrattuna aikaisempiin vuosiin, mutta silti johtajien mielestä asiakkaiden toiveita ja omaa päivärytmiä tulisi kunnioittaa enemmän. Palvelutalojen työkulttuuri on edelleen liian laitosmainen ja hoitajien työote rutiininomainen. Jotta muutos kohti kodinomaisuutta toteutuisi, tulisi lähijohtajien mukaan työvuorojen ja tehtävien jakoa uudistaa, mikä edellyttäisi hoitajilta tahtoa, osaamista, luovuutta ja itseohjautuvuutta. Asiakkaiden itsemääräämisoikeuden kunnioittamiseen hoitajat tarvitsevat rohkeutta, sillä aiheeseen liittyy eettisiä ristiriitoja: tuleeko esimerkiksi noudattaa hoitosuosituksia vai asiakkaan omaa toivetta tai kuinka toimia tilanteissa, joissa omainen on eri mieltä kuin asiakas.

Lähijohtajat näkivät kehitettävää myös vuorovaikutustaidoissa ja tavassa kommunikoida ikäihmisten kanssa. He toivoivat haastaviin tilanteisiin enemmän vuorovaikutusosaamista, jotta ei esiintyisi tilanteiden välttelyä tai epäasiallista käyttäytymistä.

Itseohjautuvuuden lähijohtajat näkivät haasteena ja toivoivat henkilöstöltä lisää omaaloitteisuutta ja rohkeutta työn kehittämiseen. Työskentelykulttuurin muutos kohti rohkaisevaa ja suvaitsevaista ilmapiiriä mahdollistaisi erilaisten toimintatapojen kokeilun. Lähijohtajat tunnistivat oman vastuunsa tukea työntekijöitä muutoksessa toimimalla esimerkkinä, kannustamalla, osoittamalla luottamusta, rohkaisemalla itseohjautuvuuteen ja oman työn luovaan kehittämiseen. Lisäksi lähijohtajan on tärkeää osoittaa aikaa suunnitteluun ja ideointiin sekä osallistaa työntekijät myös toiminnan arviointiin.

\section{Henkilöstön näkemys koulutustarpeista}

Henkilöstön itsearvioinnin mukaan useimmilla heillä oli koulutustarvetta haavanhoidosta (79\%), haastavista kohtaamistilanteista $(73 \%)$, ensiavusta (70 \%) ja saattohoidosta (68 \%). Enemmistö vastaajista tunnisti melko paljon koulutustarvetta kivunhoidosta, lääkehoidosta ja muistisairauksista. Näkemykset ravitsemuksesta ja asiakkaan mielialavaihtelujen käsittelystä hajaantuivat: puolella oli koulutustarvetta, puolella ei. Enemmistö vastaajista koki, että heillä ei ollut juurikaan koulutustarvetta suun hoitoon eikä oman työajan hallintaan tai työnilon löytämiseen. Noin puolet vastaajista arvioi, että heillä on koulutustarvetta tietokoneen käyttötaitoon.

\section{Lähijohtajien ja henkilöstön tulosten tarkastelua}

Tämän tutkimuksen mukaan henkilöstö arvioi osaavansa toteuttaa hoitotyötä niillä osa-alueilla,jotka lähijohtajat näkivät palvelutaloissa keskeisinä. Tulos vahvistaa Kiljusen (2019) sekä Tiikkaisen ja Juntusen (2018) tuloksia siitä, että vanhustyössä toimiva hoitohenkilökunta arvioi osaamisensa pääosin hyväksi. Osaamisia kysyttiin tässä tutkimuksessa melko yleisellä tasolla, eikä tulosten perusteella selviä, mitä esimerkiksi lääkehoidon osaamisella itse asiassa tarkoitetaan.

Lähijohtajien haastattelutulosten mukaan palvelutalojen henkilöstöltä odotettavassa osaamisessa painottuu ihmisen perushoitotyön osaaminen, kuten ravitsemuksen, puhtauden ja toimintakykyisyyden turvaaminen. Tulokset ovat linjassa pohjoismaisen hoitotyön vertailututkimuksen (Kröger ym. 2018) kanssa; sen tulosten mukaan laitoshoidon hoivahenkilöstöstä yli 90 prosenttia kuvasi näiden asioiden kuuluvan päivittäisiin tehtäviinsä. Toisena keskeisenä osaamisalueena lähijohtajien vastauksissa korostui kliinisen hoitotyön osaaminen, kuten perussairauksien tunteminen, lääkehoidon 
osaaminen, terveydentilan arviointikyky ja muistisairaan kohtaaminen. Tulokset ovat yhteneväiset vanhuspalveluiden osaamisraportin 2013 kanssa (Taipale-Lehto \& Bergman 2013) ja vahvistavat myös Koskisen ja Laibertin (2011) näkemystä, jonka mukaan lähihoitajien keskeisiin osaamisalueisiin kuuluvat muun muassa gerontologisen hoitotyön osaaminen ja hyvinvoinnin edistäminen.

Kun lähijohtajilta kysyttiin aihealueita, joissa henkilöstön osaamista tulisi vahvistaa, nousi esiin teemoja, joissa henkilöstö itse arvioi osaamisensa hyväksi. Vertailua hankaloittaa se, että johtajat kuvasivat lähinnä lähihoitajien osaamisen kehittämistarpeita, ja henkilöstövastaajissa taas oli mukana myös sairaanhoitajia ja hoiva-avustajia.

\section{Perushoitotyön ja kliinisen hoitotyön osaaminen}

Lähijohtajat tunnistivat ravitsemuksen turvaamisen keskeiseksi osaamisalueeksi, ja hoitotyöntekijöistä lähes kaikki ilmoittivat ymmärtävänsä ravitsemuksen merkityksen hoitotyössä ja kiinnittävänsä huomiota asukkaiden päivittäiseen syömiseen. Lisäkoulutustarvetta ravitsemukseen tunnisti vajaa puolet vastaajista. Ravitsemukseen liittyvää koulutustarvetta on todettu myös aiemmissa tutkimuksissa (Salo 2012; Koivula 2014). Näin ollen on lohdullista, että osa hoitohenkilökunnasta tunnisti tämän lisäkoulutustarpeen, jolle lienee todellista tarvetta, koska Jyväkorven (2016) tutkimuksen mukaan pitkäaikaishoidossa olevista vanhuksista lähes 70 prosentilla oli virheravitsemusriski ja 17 prosenttia oli virheravittuja. Useilla vanhuksilla ruokahalu on heikkoa ja syöminen vähäistä (Jyväkorpi 2016), eikä henkilökunnalla aina ole Pirhosen (2013) mukaan riittävästi aikaa ruokailussa apua tarvitsevien auttamiseksi. Aliravitsemusta voi aiheuttaa myös puutteellinen suunhoito (Saarela 2014), johon tämän tutkimuksen mukaan hoitotyöntekijöistä reilu kolmannes tunnisti lisäkoulutustarvetta. Tulokset viittaavat siihen, että hoitohenki- löstöllä ei välttämättä ole riittävää ymmärrystä siitä, mitä vastuu ravitsemuksen turvaamisessa tarkoittaa ja miten se eroaa maallikkotietotasoisesta ruokailussa avustamisesta.

Kliinisen hoitotyön kysymyksissä oli myös aihealueita, joissa henkilöstö arvioi omaavansa osaamista mutta joissa lähijohtajat näkivät - ja kuten myös useissa aiemmissa tutkimuksissa on havaittu - osaamisessa kehittämistarpeita. Henkilöstö arvioi osaavansa toteuttaa turvallista lääkehoitoa, mikä on ristiriitainen tulos useisiin aiempiin tutkimustuloksiin nähden. Salermon (2011) tutkimuksen mukaan vanhustyössä olevien lähihoitajien tiedot lääkehoidon perusteista olivat keskimäärin heikot, tiedot haitta- ja yhteisvaikutuksista kohtalaiset ja tiedot lääkkeistä, lääkkeiden säilyttämisestä, käsittelystä, vanhenemismuutoksista ja lääkelaskuista tyydyttävät. Hakoisen ja kumppaneiden (2017) mukaan lääkehoidon toteutuksen ja vaikutusten seurannassa on todettu paljon puutteita sekä laitos- että avohoidossa, minkä vuoksi hoitotulokset voivat olla huonoja tai jopa aiheuttaa asiakkaille estettävissä olevia haittoja. Myös Karttusen (2019) tutkimuksen mukaan hoitajat eivät aina saata lääkkeitä käyttökuntoon ohjeiden mukaan vaan murskaavat sellaisia lääkemuotoja, joita ei saa murskata, tai tyhjään mahaan otettavat lääkkeet annetaan ruuan kanssa, lääkehoidon vaikutuksia ei seurata ja kirjaamisessakin on puutteita. Lääkehoidon ollessa palvelutaloissa usein hoitajan vastuulla voi lääkehoidon seurannan puute johtaa Hakoisen ja kumppaneiden (2017) mukaan siihen, että tarvittaessa otettavat lääkkeet jäävät pysyviksi eivätkä tiedot lääkehoidon vaikutuksista välity lääkärille. Lähijohtajien haastattelut vahvistivat aiempia tutkimustuloksia, sillä johtajat tunnistivat osaamisvajeita erityisesti lähihoitajien lääkehoidon osaamisessa. Henkilöstövastaajista reilu puolet koki omaavansa jonkin verran lisäkoulutustarvetta lääkehoidossa ja kivunhoidossa; näihin kuului seitsemästä sairaanhoitajavastaajasta kuusi. Tuloksista voi tehdä johtopäätöksen, että palvelutaloissa tarvitaan keskustelua siitä, mikä on riittävä ja tavoiteltava niin lä- 
hihoitajien kuin sairaanhoitajienkin lääkehoidon osaamisen taso.

Perussairauksien ja sisätautien hoitotyön osaamisessa toistui sama ilmiö. Henkilöstö koki omaavansa näissä osaamista ammattiryhmästä riippumatta, mutta lähijohtajat arvioivat, että osaamista tulisi vahvistaa. Myös perussairauksiin liittyen tarvitaan keskustelua siitä, mikä on lähihoitajille tavoiteltava osaamisen taso.

Henkilöstö myös arvioi osaavansa asukaslähtöisen sähköisen kirjaamisen, mutta lähijohtajat näkivät siinä, esimerkiksi terveydentilassa ja voinnissa havaittujen muutosten tai lääkehoidon vaikutusten kirjaamisessa, kehitettävää. Tulosten ristiriitaa selittänee se, että henkilöstö arvioi osaavansa teknisesti kirjata asukastietoja, mutta lähijohtajat tunnistavat kirjaamisessa sisällöllisiä puutteita. Krögerin ja kumppaneiden (2018) tutkimuksessa noin 80 prosenttia vastaajista koki, että dokumentointi vie liian paljon aikaa. Tämä herättää pohtimaan, eikö kirjatulla tiedolla nähdä olevan merkitystä arjen toiminnassa. Lähijohtajien tunnistamissa kehittämistarpeissa nousi esiin sekä kirjatun tiedon että eri järjestelmien, kuten RAIn ja ViVaGon, tuottaman tiedon hyväksikäyttö. Järjestelmistä saatavan tiedon hyväksikäyttöön liittynee tietoteknisen osaamisen puute, sillä tietokoneen käytön lisäkoulutustarpeen mainitsi 22 vastaajaa. Tulokset vahvistavat Alastalon ja kumppaneiden (2018) tulosta, jonka mukaan teknologian hyödyntämisen taitoa tulisi vahvistaa.

Muistisairaudet, niiden hoito ja sairauden kanssa selviytyminen on tunnistettu aiheiksi, joissa muistisairaiden kanssa työskentelevillä on osaamisen kehittämistarpeita (Suhonen ym. 2015). Myös tämän tutkimuksen tulosten mukaan kuusi seitsemästä kyselyyn vastanneesta sairaanhoitajasta ja noin puolet lähihoitajavastaajista koki omaavansa jonkin verran koulutustarvetta muistisairauksista.

Mielenterveyspotilaan erityistarpeiden tunnistaminen oli niin ikään aihe, jossa henkilöstö koki osaamisessaan epävarmuutta ja lähes puolet tunnisti koulutustarvetta. Myös Arolaakson ja Tervaskanto-Mäentaustan (2017) tutkimustulosten mukaan vanhustyössä toimivat työntekijät kokevat mielenterveys- ja päihdeongelmia omaavien asiakkaiden kohtaamisen haasteellisena ja tarvitsevansa siihen lisää koulutusta.

Vuorovaikutusosaaminen ja asiakkaan tarpeiden parempi ymmärtäminen näyttäisivät olevan yksi tärkeimmistä osaamisen kehittämiskohteista, koska ne luovat perustan asiakaslähtöiselle työotteelle. Sekä henkilöstö että lähijohtajat tunnistivat osaamisen kehittämistarpeita vuorovaikutusosaamisessa, haastavissa kohtaamistilanteissa ja aggressiivisesti käyttäytyvän asukkaan kohtaamisessa. Asiakaskunnan haastavuus ja muistisairauksien lisääntyminen selittänevät myös sitä, että hoitohenkilökunnan kokema väkivallan uhka asiakkaan tai omaisten taholta on kaksinkertaistunut kymmenessä vuodessa (Kröger ym. 2018).

\section{Asiakaslähtöisyys ja itseohjautuvuus}

Asiakaslähtöisyys, suunnitelmallisuus ja rutiineista luopumiseen pyrkivä työote olivat teemoja, joissa henkilöstöllä oli lähijohtajien näkemysten mukaan paljon kehittämistarpeita. Asiakaslähtöisyyden edellytyksenä on ihmisen persoonan tunnistaminen, mikä Pirhosen (2017) mukaan voi palvelutaloissa jäädä toteutumatta. Samoin Riekkinen-Tuovisen (2018) mukaan asiakkaan omat tavat ja tottumukset voivat jäädä huomioimatta. Turjanmaa (2014) on puolestaan todennut, että kotihoidossa asiakkaan voimavaroja ei tunnisteta eikä huomioida vaan asiakkaan luona työskentelyä ilmentää toimenpidekeskeisyys, kiire, asiakkaan puolesta tekeminen ja keskittyminen lääkehoidon rutiininomaiseen suorittamiseen sekä välttämättömiin fyysisiin tarpeisiin vastaamiseen, mikä ei kuvasta asiakaslähtöistä ja kuntouttavaa työotetta. Myös tämän tutkimuksen tuloksista ilmeni, että lähijohtajat tunnistivat tarpeelliseksi rutiineista poisoppimisen ja uudenlaisen työn organisoinnin, mikä edellyttäisi johtajiltakin uudenlaista osaamista. Tulokset viittaavat siihen, että esimiestyöhönkin tarvittaisiin täyden- 
nyskoulutusta, kuten ilmeni myös Krögerin ja kumppaneiden (2018) tuloksista.

Työn suunnitelmallisuutta on työyhteisöissä syytä konkretisoida. Lähijohtajien mukaan hoito- ja palvelusuunnitelmien käytännön tasolle vienti ei toteudu, vaikka hoitajat arvioivat toimivansa hoitosuunnitelman mukaan. Viidesosa henkilöstövastaajista oli epävarmoja, pystyvätkö he toteuttamaan laadukasta perushoitoa, mikä ilmentää sitä, että tähän ei aina kyetä. Johtuuko tämä ennen kaikkea osaamisvajeesta, asenteista vai riittämättömästä ajasta, vai näistä kaikista yhteensä, jää arvailujen varaan. Kriittistä suhtautumista palvelun laatuun kuvastivat myös Krögerin ja kumppaneiden (2018) tulokset, joiden mukaan suomalaisesta laitoshoidon henkilöstöstä vain viidesosa käyttäisi mielellään itse vanhana oman työpaikkansa tarjoamia hoivapalveluja.

Henkilökunta ei juurikaan kokenut tarvitsevansa koulutusta työajan hallintaan tai työnilon löytämiseen, vaikka yli puolet henkilöstövastaajista ei kokenut työilmapiiriä myönteiseksi. Krögerin ja kumppaneiden (2018) selvityksen mukaan yli puolet suomalaisista hoitohenkilöstövastaajista koki itsensä usein henkisesti uupuneeksi, ja vuonna 2015 noin kaksi viidesosaa hoitajista harkitsi työn lopettamista. Koulutus sinänsä ei välttämättä ole ratkaisu uupumiseen, mutta työilmapiiriä sillä voitaisiin vahvistaa. Riittävän henkilöstömäärän turvaamiseksi vanhuspalvelulakiin (980/2012, 20§) tehtiin henkilöstömitoitusta koskevia muutoksia vuonna 2020. Riittävän henkilöstömäärän lisäksi tarvitaan osaamista ja myönteistä asennetta, jota voidaan vahvistaa hyvällä johtamisella. Työyhteisöjen ja esimiesten valmennus uudenlaisten toimintatapojen omaksumiseen voisi myös auttaa siinä, että työaikaa käytettäisiin ikäihmisten kannalta merkityksellisiin asioihin, mikä saattaisi lisätä niin asiakkaiden hyvinvointia kuin työntekijöiden työniloa (Räsänen 2017).

\section{Eettisyys ja luotettavuus}

Tutkimus toteutettiin osana EU-rahoitteista hanketta (Himanen 2019). Haastatteluun osallistuneet saivat haastattelun alussa suullisesti ja kyselyyn osallistuneet e-lomakkeen yhteydessä tiedon, jossa kerrottiin hankkeesta ja tutkimuksesta sekä osallistumisen ja kyselyyn vastaamisen vapaaehtoisuudesta. Kyselyyn vastattiin anonyymisti ja anonymiteetti taattiin myös tulosten raportoinnissa.

Kyselyaineisto kerättiin teoriatiedon pohjalta itse laaditulla mittarilla ennen haastatteluaineiston keruuta. Jos lähijohtajien haastattelu olisi toteutettu ensin, olisi sen tuloksia voitu hyödyntää henkilöstön osaamista kartoittavan kyselylomakkeen laadinnassa, jolloin tuloksia olisi voitu verrata keskenään paremmin. Tulosten yleistä vertailtavuutta olisi lisännyt valmiin luotettavaksi todetun mittarin käyttäminen.

Pieni vastaajajoukko rajoitti kvantitatiivisten tulosten analysointia, eikä tuloksia voi sen vuoksi yleistää.

Kvalitatiivisen tutkimuksen luotettavuutta tarkastellaan uskottavuuden, siirrettävyyden ja vahvistettavuuden kriteerein (Kylmä \& Juvakka 2007). Haastatteluaineiston uskottavuutta tukee palvelutalojen lähijohtajien asema relevantteina tiedonantajina. Tutkimustulosten siirrettävyyttä ja vahvistettavuutta tukevat aikaisempien tutkimusten samansuuntaiset tulokset.

Kokonaisuudessa tutkimusta voidaan tarkastella aineistolähtöisenä tapaustutkimuksena (Häikiö \& Niemenmaa 2007). Tuloksia voidaan pitää erityisesti keskustelua herättävinä sekä palvelutalojen henkilöstön ja lähijohtajien toimintatapojen kehittämistyötä stimuloivina.

\section{Päätelmät}

Tutkimuksen keskeisenä tuloksena voidaan todeta, että hoitohenkilöstön itsearvioimassa osaamisessa ja lähijohtajien näkemyksissä henkilökunnan osaamisesta on eroja. Vanhustyön 
työyhteisöissä tarvittaisiin enemmän keskustelua siitä, millaista osaamisen tasoa lähihoitajilta edellytetään ja millaisista tiedoista ja taidoista osaaminen konkreettisesti muodostuu.

Lähijohtajat tarvitsisivat valmennusta työnjohdollisiin taitoihin, sillä heillä näyttää tämän tutkimuksen tulosten perusteella olevan hyvä käsitys siitä, millaisia asioita kehittämällä hoitotyön laatua saataisiin parannettua. Vanhustyössä ei voida nojautua ainoastaan henkilöstön itseohjautuvuuteen, vaan työtä on johdettava ja laatua valvottava. Muutoksiin liittyy totutuista toimintatavoista luopumista, jolloin tarvitaan jämäkkää johtamista.

\section{Lähteet}

Aejmelaeus R, Hetemäki M. Vanhusten hoidon ongelmat, osa 1. Valtioneuvosto, Ajankohtaista, 2019. Internet: https://valtioneuvosto.fi/artikkeli/-/asset_publisher/10623/vanhusten-hoidon-ongelmat-osa-1 (viitattu 7.1.2020).

Alastalo H, Kehusmaa S, Hammar T, Marjeta N. Kotihoidossa lisäkoulutustarvetta päihde- ja mielenterveysosaamisessa - osaamista muistisairaan itsemääräämisoikeuden tukemisessa myös vahvistettava. Tutkimuksesta tiiviisti 38. Helsinki: Terveyden ja hyvinvoinnin laitos, 2018.

Arolaakso S, Tervaskanto-Mäentausta T. Toimintakyvyn arvioinnista vanhustyön arjessa - kuvaus Eheä Elämän Ehtoo -hankkeesta. Gerontologia 2017;31(4):291-300.

Bing-Jonsson PC, Hofoss D, Kirkevold M, Bjørk IT, Foss C. Sufficient competence in community elderly care? Results from a competence measurement of nursing staff. BMC Nurs 2016;15:5. https://doi.org/10.1186/s12912-016-0124-z

Hakoinen S, Laitinen-Parkkonen P, Airaksinen M. Lääkekaaoksen hallinta sote-muutoksessa, nykytila, haasteet ja ratkaisuehdotukset. Kaks - Kunnallisalan kehittämissäätiö, Tutkimusjulkaisu 106, 2017.

Himanen S, toim. Digitaalisen itseopiskeluympäristön kehittäminen vanhustyön hoivahenkilöstön täydennyskoulutusvälineeksi. Tampere: Tampereen ammattikorkeakoulu, 2019. Internet: https://www.tamk.fi/-/digitaalisen-itseopiske-
Toisen asteen ammatillisen koulutusuudistuksen myötä oppiminen painottuu työpaikoilla toteutuvaan opiskeluun ja harjoitteluun (Laki ammatillisesta koulutuksesta 531/2017), minkä seurauksena opiskelijat omaksuvat yhä herkemmin työpaikan käytäntöjä (Holmström 2017). Tästäkin syystä niin hoitohenkilökunnan kuin lähijohtajienkin osaamiseen ja täydennyskoulutukseen on syytä panostaa.

\section{Yhteydenotto:}

Sari Himanen, esh, FT, yliopettaja

Tampereen ammattikorkeakoulu sari.himanen@tuni.fi

luympariston-kehittaminen-vanhustyon-hoivahenkiloston-taydennyskoulutusvalineeksi (viitattu 7.1.2020).

Holmström AR. Learning from medication errors in healthcare - how to make medication error reporting systems work? Doctoral dissertation. Helsinki: University of Helsinki, 2017.

Häikiö L, Niemenmaa V. Valinnan paikat. Teoksessa: Laine M, Bamberg J, Jokinen P, toim. Tapaustutkimuksen taito. Helsinki: Gaudeamus, 2007:4156.

Jyväkorpi S. Nutrition of older people and the effect of nutritional interventions on nutrient intake, diet quality and quality of life. Doctoral dissertation. Helsinki: University of Helsinki, Faculty of Medicine, Department of General Practice and Primary Health Care, 2016.

Karttunen M. Lääkehoidon turvallinen toteuttaminen ikääntyneiden pitkäaikaishoidossa hoitohenkilöstön arvioimana. Acta Universitatis Ouluensis D 1527. Oulu: Oulun yliopisto, 2019.

Kiljunen O. Care home nursing professionals' competence in older people nursing. Dissertations in Health Sciences 492. Kuopio: University of Eastern Finland, 2019.

Koivula K. Kotihoitohenkilöstön ammatilliset valmiudet asiakkaiden ravitsemuksen ja ruokailun tukemisessa. Yamk-opinnäytetyö. Tampere: Tampereen ammattikorkeakoulu, 2014. 
Koskinen ML, Laibert P. Lähihoitaja tulevaisuuden hoitotyön osaajana. Teoksessa: Vesterinen ML, toim. Sote-ennakointi - sosiaali- ja terveysalan sekä varhaiskasvatuksen tulevaisuuden ennakointi. Raportteja ja tutkimuksia 3. Etelä-Karjalan koulutuskuntayhtymä, 2011.

Kröger T, Van Aerschot L, Puthenparambil JM. Hoivatyö muutoksessa: suomalainen vanhustyö pohjoismaisessa vertailussa. YFI julkaisuja 6. Jyväskylä: Jyväskylän yliopisto, 2018.

Kylmä J, Juvakka T. 2007. Laadullinen terveystutkimus. Helsinki: Edita.

Laki ammatillisesta koulutuksesta 531/2017.

Laki terveydenhuollon ammattihenkilöistä 559/1994, $1659 / 2015$.

Lodigo M, Spaulding D, Voegtle K. Methods in educational research: from theory to practice. San Francisco: Jossey-Bass, 2006.

Pirhonen J. Toimintamahdollisuudet vanhojen ihmisten pitkäaikaishoidossa. Gerontologia 2013; 27(2):58-72.

Pirhonen J. Good human life in assisted living for older people: what the residents are able to do and be. Dissertion in Faculty of Social Sciences. Acta Universitatis Tamperensis 2272. Tampere: Tampere University Press, 2017.

Riekkinen-Tuovinen S. Sosiokulttuurista vanhustyötä paikantamassa: tutkimus erilaisissa vanhusten asumisympäristöissä. Dissertations in Social Sciences and Business Studies 164. Kuopio: University of Eastern Finland, 2018.

Räsänen R. Hoitajien työajan merkitys asiakkaiden elämänlaadulle vanhusten ympärivuorokautisessa hoidossa. Gerontologia 2017;31(2):116-32.

Saarela R. Oral and nutritional problems among residents in assisted living facilities. Doctoral dissertation. Helsinki: University of Helsinki, Faculty of Medicine, Department of General Practice and Primary Health Care, 2014.

Saarela M, Suominen T, Roos M. Sosiaali- ja tervey- denhuoltouudistuksesta aiheutuvat haasteet vanhuspalveluiden esimiesten kuvaamana. Hoitotiede 2019;31(2):87-98.

Salermo E. Lähi- ja perushoitajien lääkehoito-osaaminen vanhustyössä. Gerontologian ja kansanterveyden pro gradu -tutkielma. Jyväskylän yliopisto, Terveystieteiden laitos, 2011.

Salo V. Kotipalvelun työntekijöiden koulutustarpeet ja ammatillisen kasvun tukeminen iäkkäiden ruokailuun ja ravitsemukseen liittyen. Annales Universitatis Turkuensis C 329. Turku: Turun yliopisto, Kasvatustieteiden tiedekunta, 2012.

Suhonen R, Röberg S, Hupli M, Koskenniemi J, Stolt M, Leino-Kilpi H. Muistipotilaiden optimaalisen palvelukokonaisuuden ominaisuudet. Hoitotiede 2015;27(4):259-73.

Taipale-Lehto U, Bergman T. Vanhuspalveluiden osaamistarveraportti. Raportit ja selvitykset 2013:14. Opetushallitus, 2013.

Tiikkainen P, Juntunen K. Kukoistava kotihoito: kotihoidon työntekijöiden itsearvioitu osaaminen. Jyväskylän ammattikorkeakoulun julkaisuja 253. Jyväskylä, 2018.

Turjamaa R. Iäkkäiden ihmisten yksilölliset voimavarat ja niiden huomioiminen kotihoidossa. Dissertations in Health Sciences 255. University of Eastern Finland, 2014.

Vanhuspalvelulaki 980/2012. Laki ikääntyneen väestön toimintakyvyn tukemisesta sekä iäkkäiden sosiaali- ja terveyspalveluista. Internet: www.finlex.fi (viitattu 7.1.2020).

Voutilainen P, Löppönen M. Hyvä ympärivuorokautinen hoito. Käypä hoito. Suomalainen Lääkäriseura Duodecim, 2016. Internet: http://www. kaypahoito.fi/web/kh/suositukset/suositus?id=nix01676 (viitattu 7.1.2020).

Voutilainen P, Routasalo P, Isola A, Tiikkainen P. Gerontologisen hoitotyön tietoperusta. Teoksessa: Voutilainen P, Tiikkainen P, toim. Gerontologinen hoitotyö. Helsinki: WSOY, 2009:12-26. 